Zaritska, N. Yu. (2014). Zmina smyslozhyttievykh tsinnostei yak peredumova poiavy alternatyvnykh styliv zhyttia, zasnovanykh na dobrovilnii mobilnosti [Changing the meaning of life values as a prerequisite for the emergence of alternative lifestyles based on voluntary mobility]. Hrani. № 2. S. 123-126. [in Ukrainian].

Graves, C. W. (1970). Levels of Existence: an Open System Theory of Values. The Journal of Humanistic Psychology. № 10 (2). Pp. 131-155. [in English].

Pelekh, Yu., Kukla, D. (2019). Systema tsinnostei maibutnoho fakhivtsia i yoho mistse na suchasnomu rynku pratsi [Value system of future specialist and its place in labor market ]. Rivne: Volynski oberehy. 184 s. [in Ukrainian].

Landy, F. J. (2006). The long, frustrating and fruitless search for social intelligence: a cautionary tale. A critique of emotional intelligence: what are the problems and how can they be fixed? / K. R. Murphy (ed.). New Jersey: Lawrence Erlbaum Associates. Pp. 81-123. [in English].

Weis, S. (2008). Theory and measurement of social intelligence as a cognitive performance construct: dissertation zur erlangung des akademischen grades doktor der philosophie. Magdeburg. URL: http://diglib.uni-magdeburg.deDissertationen/2008/suzweis.pdf (Date of access: 30.03.2021). [in English].

Olport, H. (1998). Lichnost v psikhologii [Personality in psychology]. Moskva: KSP+. 345 c. [in Russian].

Mykhailova (Alëshyna), E. S. (2001). Test Dzh. Hylforda y M. Sallyvena. Diagnostika sotsialnogo intellekta. Rukovodstvo polzovatelya [Test by J. Guilford and M. Sullivan. Diagnostics of social intelligence. User's manual]. Sankt-Peterburg: GP «Imaton». 56 s. [in Russian].

Kharchenko, S. V. (2016). Rol umov sotsializatsii $\mathrm{v}$ rozvynenni sotsialnoho intelektu osobystosti [The role of socialization conditions in the development of social intelligence of the individual]. Pravo i Bezpeka. № 2. S. 146-151. [in Ukrainian].

УДК 37.091.12:159.9]:005.336.2

DOI: 10.37026/2520-6427-2021-106-2-83-88
Kuzminskiy, A. I. (2011). Tsennostnye orientiry sovremennogo obrazovaniya. [Value guidelines of modern education]. Tsennosti professionalnoy deyatelnosti sovremennogo pedagoga: mezhvuzovskiy sbornik nauchnykh trudov / pod obshch. red. M. I. Lukyanovoy, Ye. A. Lodatko. Cherkassy; Ulyanovsk: UIPKPRO. S. 47-55. [in Russian].

Andreeva, Y. N. (2011). Emotsionalnyy intellekt kak fenomen sovremennoy psikhologii [Emotional intelligence as a phenomenon of modern psychology]. Novopolotsk: PHU. 388 s. [in Russian].

Houlman, D., Makky, Э., Boiatsys, R. (2012). Emotsionalnoe liderstvo: iskusstvo upravleniya lyudmi na osnove emotsionalnogo intellekta [Emotional Leadership: The Art of Managing People Based on Emotional Intelligence]; per. s angl. 6-e izd. Moskva: Alpina Pablisher. [in Russian].

Bar-On, R. (2005). Model of emotional-social intelligence. Special Issue on Emotional Intelligence / P. Fernández-Berrocal and N. Extremera (Guest Editors). Psicothema. № 17. URL: https://www.researchgate.net/ publication/6509274_The_Bar-On_Model_of_Emotional-Social_Intelligence (Date of access: 30.03.2021). [in English].

Bar-On, R. (1997). Emotional Intelligence Inventory (EQ-I): Technical Manual. Toronto: Multi-Health System. [in English].

Matviichuk, A. V. (2002). Ekolohichne znannia ta styl myslennia suchasnoi nauky [Ecological knowledge and thinking style of modern science]: monohrafiia. Rivne: Lista-M. 147 s. [in Ukrainian].

Дата надходження до редакиіï: 21.05.2021 p.

Тетяна АБРАМОВИЧ,

кандидат педагогічних наук, старший викладач кафедри педагогіки, психології та корекиійної освіти, методист Ресурсного иентру підтримки інклюзивної освіти Рівненського обласного інституту післядипломної педагогічної освіти, м. Рівне, Украӥна

ORCID: 0000-0002-5057-2301

e-mail: t.abramovych@roippo.org.ua

\title{
ПСИХОЛОГІЧНА КОМПЕТЕНТНІСТЬ У ПРОФЕСІЙНОМУ РОЗВИТКУ ПЕДАГОГА НОВОЇ УКРАЇНСЬКОЇ ШКОЛИ
}

\begin{abstract}
Анотація. У статті зроблено акцент на необхідності психологізації освітнього процесу через підвищення рівня психологічної компетентності всіх його учасників, передусім учителів. Наголошено на важливості прийняття професійного стандарту вчителя, доведено, щзо означений документ не лише
\end{abstract}

регулюватиме фаховий розвиток педагога, а й сприятиме побудові траєкторії його професійного розвитку. Здійснено частковий розгляд професійного стандарту вчителя на прикладі аналізу психологічної компетентності, яка має на меті поєднання низки чинників, зокрема здатність учителя визначати $i$ 
враховувати в освітньому прочесі вікові й індивідуальні особливості учнів, щзо передбачає орієнтацію вчителя на якісне $і$ всебічне вивчення розвитку дитини, ї стартових можливостей, які впливають на навчальні здібності й адаптивні процеси, визнання унікальності суб 'єктивного досвіду здобувачів освіти; використовувати стратегії роботи зі здобувачами освіти, які сприяють розвитку їхньої позитивної самооиінки, Я-ідентичності, пошуку шляхів становлення рольовоі ідентичності з опорою на розуміння інтеграції ролей особистості в єдину иілісність; формувати мотиваиійну сферу учнів, організовувати їхню пізнавальну діяльність, завдяки чому в дітей розвиваються ключові компетентності; створювати в класі спільноту учнів, завдяки якій розкривається індивідуальність кожної дитини, визначається ї̈ місие в колективі, адже від входження дитини у спільноту ровесників залежить, як у майбутньому відбуватиметься ї адаптація та самореалізація в сочіумі. Зазначається, щзо, організовуючи психолого-педагогічний супровід кожного учня, педагог має керуватися принциипами соиіального партнерства (розподіл функиій, добровільність прийняття зобов'язань, обов'язковість виконання домовленостей, рівноправність учасників, взаємоузгодженість у виконанні спільних дій тощо).

Ключові слова: психологічна компетентність, професійний стандарт, траєкторія професійного розвитку, ідентичність, мотивачія, спільнота.

\section{PSYCHOLOGICAL COMPETENCE IN THE PROFESSIONAL DEVELOPMENT OF THE NEW UKRAINIAN SCHOOL TEACHER}

\begin{abstract}
The article deals with psychologization educational process by increasing the level of psychological competence of all its participants, especially teachers. The importance of adopting a professional standard of a teacher is emphasized. It has been proved that this paper will not only regulate the professional development of a teacher, but also contribute to the construction of the trajectory of its professional development.

A partial consideration of the professional standard of a teacher is carried out on the example of the analysis of psychological competence, which aims to combine a number of factors. In particular, the teacher's ability to determine and take into account in the educational process the age and individual characteristics of students, which involves the teacher's focus on quality and comprehensive study of child development. Its starting points, which affect learning abilities and adaptive processes, recognition of the uniqueness of students subjective experience. Using the working strategy with students that promote the development of their positive self-esteem, selfidentity and finding ways to form a role identity based on understanding the integration of personal roles into a single whole. Formation of the motivational sphere of students and organization of their cognitive activity that leads to development of to children's key competencies. Also, the creation of a community of students in the
\end{abstract}

classroom, which reveals the individuality of each child and determines its place in the team. After all, the child's entry into the community of peers depends on how in the future it will adapt and self-realization in society.

It has been noted that organizing of psychological and pedagogical support of each student, the teacher should be guided by the principles of social partnership (division of functions, voluntary commitment, mandatory implementation of agreements, equality of participants, coherence in joint actions, etc.).

Key words: psychological competence, professional standard, trajectory of professional development, identity, motivation, community.

Постановка проблеми. Початком освітньої реформи в Україні, покликаної модернізувати концептуальні засади всіх освітніх ланок, змінити стереотипне ставлення громадськості до розуміння сутності освітньої парадигми, сформувати нові стандарти і результати навчання, стало прийняття Законів України «Про освіту» (2017) та «Про повну загальну середню освіту» (2020), Концепції «Нова українська школа» (2016), Державного стандарту початкової освіти (2018) та Державного стандарту базової середньої освіти (2020).

Концепцією Нової української школи серед низки пріоритетів у розвитку освіти визначено особистісно 
орієнтоване навчання і виховання, що передбачає психологізацію освітнього процесу шляхом підвищення рівня психологічної компетентності всіх його учасників: здобувачів освіти, батьків, учителів.

Діяльність учителя $є$ поліфункіональною та передбачає реалізацію певних компетентностей, аби діяти якісно й ефективно, бути конкурентоздатним та успішним. Науковцями давно доведено, що педагоги - це не тільки «змінна величина», необхідна для успішного реформування освітньої системи, а передусім «найбільш визначний носій змін» у реалізації реформ. Ця дуальна роль учителя в освітніх реформах - бути суб'єктом i об'єктом трансформацій - робить професійний розвиток учителів «зоною виклику» (Пуховська, 2011, с. 97-106).

В умовах постійних динамічних змін, що стосуються знань, технологій, інформації, обставин життя, людство постало перед фактом, що знання оновлюються навіть швидше ніж відбувається зміна поколінь (Огнев'юк, 2013, с. 6-11). Така ситуація обумовлена тим, що отримані знання дуже швидко «старіють», виникає потреба не лише в здобутті нових, а й у постійному їх оновленні, неперервній освіті педагогів. До того ж динаміка змін на ринку праці в умовах світової економічної кризи ускладнює педагогічні проблеми підготовки конкурентоспроможних фахівців.

Аналіз наукових досліджень і публікацій. Метою професійної діяльності педагога є створення умов для гармонійного розвитку особистості здобувача освіти, його самореалізації, розкриття індивідуальності, творчого потенціалу. Учитель має осмислити унікальність і неповторність кожного учня як особистості із властивими їй індивідуальними особливостями, враховувати складність, неоднозначність та суперечність процесу його становлення, а також свою відповідальність як фахівця, професіонала, в контексті змін, що зазначені у нормативно-правових документах. У працях І. Беха, В. Галузинського, С. Гончаренка, Ю. Завалевського, Г. Костюка, В. Кременя, М. Лещенко, В. Моляко, Н. Ничкало, І. Підласого, В. Рибалки, О. Романовського, М. Фіцули та ін. у різних аспектах розглянуто проблему розвитку та становлення сучасного педагога, зокрема й психологічну компетентність.

Мета статті - схарактеризувати складові психологічної компетентності професійного розвитку вчителя в умовах реформування освіти та впровадження нового професійного стандарту.

Виклад основного матеріалу дослідження. Підгрунтям для здійснення дослідження стало впровадження професійного стандарту вчителя закладу загальної середньої освіти, про що зазначено в наказі Міністерства розвитку економіки, торгівлі та сільського господарства України «Про затвердження професійного стандарту за професіями «Вчитель початкових класів закладу загальної середньої освіти», «Вчитель закладу загальної середньої освіти», «Вчитель 3 початкової освіти (з дипломом молодшого спеціаліста)» від 23.12.2020 р. № 2736 (2020). Згідно з означеним документом визначено п'ять загальних компетентностей учителя: громадянську, соціальну, культурну, лідерську та підприємницьку. Кожна загальна компетентність уміщує низку трудових функцій, які відповідно об'єднують ряд професійних компетентностей (за трудовою дією або групою трудових дій).
Трудова функція «партнерська взаємодія з учасниками освітнього процесу» передбачає оволодіння вчителем такими компетентностями: психологічною, емоційно-етичною та педагогічного партнерства.

Психологічна компетентність включає низку взаємообумовлених чинників, як-от: здатність визначати і враховувати в освітньому процесі вікові та інші індивідуальні особливості учнів; здатність використовувати стратегії роботи з учнями, які сприяють розвитку їхньої позитивної самооцінки, Я-ідентичності; здатність формувати мотивацію учнів та організовувати їхню пізнавальну діяльність; здатність формувати спільноту учнів, в якій кожен відчуває себе ії частиною (наказ МОН України «Про затвердження професійного стандарту», 2020).

Обгрунтуємо кожен із представлених вище чинників докладніше.

Одним із головних принципів навчання в сучасній школі є особистісно орієнтований, що передбачає поглиблене вивчення індивідуальних особливостей дитини, зокрема й психологічних. Нова українська школа передбачає організацію особливого освітнього середовища, врахування віковідповідної діяльності, в якій дитина могла б себе реалізувати. Визначальним для вибору форм взаємодії і способів реалізації навчання $є$ врахування педагогами вікових криз учнів, наприклад, «кризи семи років» чи «кризи підліткового віку». Ураховуючи провідний канал сприйняття, тип темпераменту, тривалість фокусування уваги, об'єм запам'ятовування інформації, переважання довільних / мимовільних мислительних операцій тощо, учитель за принципом індивідуалізації чи диференціації вибудовує освітній процес. Одним із перших, хто наполягав на «врахуванні в навчально-виховній роботі вікових особливостей дітей» був Я. А. Коменський. Саме він висунув та обгрунтував принцип природовідповідності, згідно з яким освітній процес має будуватися з урахуванням вікових особливостей розвитку кожної дитини.

Із входженням дитини у середовище закладу загальної середньої освіти змінюється ії психологічний портрет, розвиваються особистісні якості та психічно-пізнавальні процеси, сфера емоцій і переживань, трансформуються інтереси й уподобання. Упродовж усього періоду навчання поступово відбуваються значні зміни у сфері соціальних відносин і діяльності на фоні перебудови всіх систем і функцій організму, що передбачає зростання напруження та мобілізацію наявного резерву. Як наслідок - учитель має орієнтуватися на якісне і всебічне вивчення розвитку дитини, іiі стартових можливостей, а особливо - труднощів, що впливають на навчальні здібності й адаптивні процеси. Особистісно орієнтоване навчання, покладене в основу концепції Нової української школи, грунтується на визнанні унікальності суб'єктивного досвіду здобувачів освіти, набутого в активній взаємодії зі світом, як важливого джерела індивідуальної життєдіяльності.

Наступний чинник, що забезпечує психологічну компетентність учителя, - це здатність використовувати стратегії роботи з учнями, що сприяють розвитку їхньої позитивної самооцінки, Я-ідентичності. 
Під поняттям «ідентичність» дослідники розуміють внутрішній, індивідуальний стан особистості, в якому виражається усвідомлення нею себе як суб' єкта діяльності із наявними цілями, мотивами і смисложиттєвими установками (Бех, Журба, 2017, с. 24-33). Еріксон тлумачив ідентичність як фрагмент ментальності індивіда, тобто добре засвоєний та особистісно прийнятий образ себе у системі відносин особистості до світу, почуття адекватності й адекватне володіння особистістю власним «Я» незалежно від змін цього «Я» і ситуації, а також здатність до конструктивного вирішення проблем, що постають перед людиною у різних сферах іiі життєдіяльності; стан внутрішньої стабільності індивіда, його безперервне переживання себе як цілісності (Эриксон, 1996, с. 59-72).

Упродовж навчання, шкільної і позашкільної активності, у стосунках із членами сім'ї, родиною, друзями, однокласниками, вчителями здобувач освіти формується як особистість, розвиваючи власне «Я» та усвідомлюючи приналежність до різноманітних суспільних груп, як великих, так і малих. Результатом такого складного процесу конструювання цього «Я» і $є$ ідентичність. Становлення ідентичності триває впродовж усього життя. Ідентичність $є$ невід'ємною характеристикою, без якої людина не може існувати як особистість. Ї̈̈ формування сприяє збереженню і підтримці цілісності й неповторності кожної людини, що проявляється в особистісних якостях, рисах характеру, ціннісних орієнтирах. Отже, процес формування ідентичності особистості є складним та багатовимірним.

Становлення особистісної ідентичності - головне завдання етапу дорослішання, а ії пошуки в ранньому юнацькому віці відбуваються як на рівні мікрогруп, дружніх компаній, так і в класній спільноті. Саме в шкільному колективі в учня можуть «закріпитися» ті ролі, які визначатимуть особливості формування його Я-концепції та довгострокові ідентифікації в майбутньому. Якщо спочатку ідентичність у дитини формується шляхом проєктування ціннісних орієнтацій, норм та ролей, приписаних батьками, то, дорослішаючи, юнаки / дівчата відчувають потребу в самоідентичності, досягати яку прагнуть самотужки. Зважаючи на це, в основу пошуків ідентичності покладено питання типу: «Хто Я?», «Яким / якою я хотів / хотіла б стати?», «Ким я є, які мої ролі?», «За кого мене сприймають у колективі?» та ін.

Методи оптимізації становлення рольової ідентичності здобувача освіти вчителеві необхідно розробляти, зважаючи на розуміння іï як показника інтеграції ролей особистості в єдину цілісність, знаходження варіантів поєднання рольових очікувань від найближчого соціального оточення та індивідуальних рольових уявлень.

Якщо вчитель у класному середовищі сформував тенденцію до цінування ролі «відповідальної людини», «помічника», «опори», то психолого-педагогічний клімат класу буде характеризуватися як позитивний. Якщо ж ці ролі нівелюються, то в класі зростатиме кількість конфліктних ситуацій.

Наступною складовою психологічної компетентності професійного стандарту вчителя є його вміння мотивувати учнів та впливати на їхню пізнавальну діяльність.
Мотивація - це спонукання до дії; динамічна система психологічних факторів, які зумовлюють навчальну діяльність (потреби, мотиви і все, що входить у мотиваційну сферу особистості). Мотивація $\epsilon$ тим критичним чинником, що формує бажання учнів навчатися в закладі освіти та поза ним. Зважаючи на психічні особливості, перебіг, мотиви поділяють на: зовнішні та внутрішні; усвідомлені та неусвідомлені; реальні та уявні.

Внутрішню мотивацію визначають чинники, внутрішньо детерміновані в особистісному «Я» здобувача освіти і його поведінці. Якщо діяльність учня $є$ самоціллю, а не засобом для досягнення іншої мети, i він прагне ії̈ покращити, то це - приклад внутрішньо вмотивованої поведінки. Саме внутрішня мотивація найбільш позитивно впливає на пізнавальні процеси та розвиток особистості загалом. Важливим фактором розвитку внутрішньої мотивації є зміст самої діяльності: вона повинна мати оптимальний рівень складності. Зовнішня мотивація доцільна у процесі вирішення певних (часткових) завдань.

Діяльність здобувача освіти $є$ полімотивованою. У зв'язку з цим один із мотивів є основним (провідним), а інші - другорядними. Особливість провідних мотивів полягає в тому, що, крім функцій спонукання діяльності, вони надають їй певного суб'єктивного особистісного змісту.

На різних етапах життєдіяльності учня йому потрібна залучаюча або притягуюча (початкова) й утримуюча (тривала) мотивації. Так, якщо притягуюча мотивація є короткостроковою, але інтенсивною, то утримуюча - довготривалою, рівномірною і постійною, хоча й зі значно зниженою інтенсивністю (Кушнір, 2015).

Утримуючу мотивацію можна формувати завдяки: поєднанню відомого і складного, різноманітних технологій і методик навчання; створенню когнітивного конфлікту; поєднанню матеріалу, що вивчається, із життям учнів; готовності до того, що рівень зацікавленості учнів досить гнучкий; дозуванню подачі матеріалу тощо.

Учитель $є$ значимим мотиватором для учнів. Знаючи мотиви здобувача освіти, педагог завжди віднайде причини і шляхи подолання труднощів. Формування мотиваційної сфери необхідно здійснювати у двох напрямах: з одного боку, розвивати мотиви обов'язку, суспільної значущості учіння, а 3 іншого - вчити розуміти суб' єктивну значущість учіння, забезпечувати розвиток здібностей, нахилів, професійної орієнтації.

Ключове значення для процесу засвоєння знань має емоційно-чуттєва сфера. Емоційні хвилювання (радість, здивування, сум, страх, співчуття тощо) передусім викликає активна позиція вчителя, зміст навчального матеріалу. Для розвитку почуттів важливо бути відвертим, створити атмосферу емоційного комфорту. Ефективним у зв'язку з цим є індивідуальний підхід до здобувача освіти.

Мотиваційна сфера учнів часто потребує збагачення і корекції з метою підвищення ефективності освітньої діяльності. Для цього спочатку необхідно ретельно дослідити мотиви конкретного учня, а вже на їх основі за певним алгоритмом сформувати нові. 
Психологічний компонент професійного стандарту педагога включає і його здатність формувати спільноту учнів, в якій кожен відчуває себе ії частинкою. Створення вчителем спільноти учнів $є$ одним із пріоритетних завдань Нової української школи. Спільнота - це об'єднання людей, згуртованих спільними умовами життя, метою (цілями) та інтересами (Великий тлумачний словник сучасної української мови, 2001, с. 1368). Саме спільнота дає здобувачам освіти відчуття значимості, потрібності, адже всі ії учасники пов'язані між собою колективними інтересами і цінностями. Члени спільноти навчаються один в одного, розширюють свої знання і досвід. У зв'язку з цим у новій українській школі особливе значення надається колективній діяльності, яка спонукає здобувачів освіти до взаємодії через виконання завдань у парах, створення проєктів у мікрогрупах тощо. Так, групова робота позитивно впливає на формування самостійності учня. Працюючи в колективі, учень вчиться проявляти ініціативу, планувати свої дії та співставляти їх із діями оточуючих, розвивати асертивність та відповідальність за себе і за колектив. Роль учителя за цих обставин особливо ефективна як в організації дієвої співпраці між членами спільноти, так і в налагодженні стосунків у системі «учитель - здобувач освіти».

На нашу думку, формуючи спільноту в класі, завдання вчителя -спрямувати свої зусилля на розкриття індивідуальності кожної дитини, допомогти їй віднайти своє місце в колективі. Від періоду входження дитини у спільноту ровесників залежить те, як у подальшому відбуватиметься іiі адаптація, якими будуть iї академічні успіхи і, звичайно, самореалізація в соціумі.

Створення спільноти в класі вчитель досягає через створення психологічно комфортного, безпечного середовища, для якого характерні оптимізм, демократичність, доброзичливість, взаєморозуміння, довіра у стосунках, взаємодопомога. Організовуючи психолого-педагогічний супровід кожного учня, педагог має керуватися принципами соціального партнерства, як-от: розподіл функцій, добровільність прийняття зобов' язань, обов'язковість виконання домовленостей, рівноправність учасників, взаємоузгодженість у виконанні спільних дій та ін.

Висновки. Професійний стандарт учителя визначає нові підходи до змісту професійної діяльності педагогів, їхні загальні та професійні компетентності. Плануючи підвищення кваліфікації, вчителі не лише матимуть змогу оцінити тематику та рівень послуг, які пропонують надавачі цих послуг у рамках підвищення кваліфікації педагогічних працівників, а й здійснити самоаналіз професійної діяльності, скорегувати напрями здобуття знань, продіагностувати наявний рівень розвитку компетентностей. За результатами самоаналізу вчитель може створити власну траєкторію професійного розвитку, що визначатиме ті компетентності, які варто розвивати.

Перспективи подальших досліджень у даному напрямі плануємо спрямувати на більш грунтовне дослідження професійного розвитку педагога, зокрема його професійних компетентностей.

\section{СПИСОК ВИКОРИСТАНОЇ ЛІТЕРАТУРИ}

Пуховська, Л. (2011). Теоретичні засади професійного розвитку педагогів: рух до концептуальної карти. Порівняльна професійна педагогіка. Хмельницький: ХНУ. № 1. C. 97-106. URL: http://khnu.km.ua/root/res/27001-31.pdf (дата звернення: 10.03.2021).

Огнев’юк, В. (2013). Багатомірна людина. Епоха трансформації. Освіта. Неперервна професійна освіта: теорія і практика. Київ. Вип. 1/2. C. 6-11. URL: http:// npo.kubg.edu.ua/article/view/186366/185670 (дата звернення: 21.02.2021).

Про затвердження професійного стандарту за професіями «Вчитель початкових класів закладу загальної середньої освіти», «Вчитель закладу загальної середньої освіти», «Вчитель 3 початкової освіти (з дипломом молодшого спеціаліста)»: наказ МОН України від 23.12.2020 р. № 2736. URL: https://www.me.gov. ua/Documents/Detail?lang=uk-UA\&id=22469103-4e364d41-b1bf-288338b3c7fa\&title=RestrProfesiinikhStanda rtiv (дата звернення: 22.03.2021).

Бех, І., Журба, К. (2017). Концепція формування у підлітків національно-культурної ідентичності у загальноосвітніх навчальних закладах. Гірська школа українських Kapnam. № 16. C. 24-33. URL: https:// core.ac.uk/download/pdf/154283942.pdf (дата звернення: 07.02.2021).

Эриксон, Э. (1996). Детство и общество; пер. с англ. Санкт-Петербург: Ленато, АСТ, Фонд «Университетская книга». 592 с.

Кушнір, Р. (2015). Треті 100000 кроків до успіху. Дрогобич: Коло. 152 с.

Великий тлумачний словник сучасної української мови. (2005) / укл. і гол. ред. В. Т. Бусел. Київ; Ірпінь: Перун. 1728 c. URL: http://irbis-nbuv.gov.ua/ulib/item/ UKR0000989 (дата звернення: 30.04.2021).

\section{REFERENCES}

Pukhovska, L. (2011). Teoretychni zasady profesiinoho rozvytku pedahohiv: rukh do kontseptualnoi karty [Theoretical bases of professional of teachers development: movement to a conceptual map]. Porivnialna profesiina pedahohika. Khmelnytskyi: KhNU. № 1. S. 97-106. URL: http://khnu.km.ua/root/res/2-7001-31.pdf. (data zvernennia: 10.03.2021). [in Ukrainian].

Ohneviuk, V. (2013). Bahatomirna liudyna. Epokha transformatsii. Osvita [Multidimensional human. The epoch of transformation. Education]. Neperervna profesiina osvita: teoriia i praktyka. Kyiv. Vyp. 1/2. S. 6-11. URL: http://npo.kubg.edu.ua/article/view/186366/185670 (data zvernennia: 21.02.2021). [in Ukrainian].

Pro zatverdzhennia profesiinoho standartu za profesiiamy «Vchytel pochatkovykh klasiv zakladu zahalnoi serednoi osvity», "Vchytel zakladu zahalnoi serednoi osvity», "Vchytel z pochatkovoi osvity (z dyplomom molodshoho spetsialista)» [About the statement of the professional standard on the professions «The teacher of initial classes of establishment of general secondary education», "The teacher of establishment of general secondary education», «The teacher of primary education (with the diploma of the junior specialist)»]: nakaz MON Ukrainy vid 23.12.2020 r. № 2736. URL: https://www. 
me.gov.ua/Documents/Detail?lang=uk-UA\&id=224691034e36-4d41-b1bf-288338b3c7fa\&title=RestrProfesiinikhStan dartiv (data zvernennia: 22.03.2021). [in Ukrainian].

Bekh, I., Zhurba, K. (2017). Kontseptsiia formuvannia u pidlitkiv natsionalno-kulturnoi identychnosti u zahalnoosvitnikh navchalnykh zakladakh [The concept of national and cultural identity formation in adolescents at secondary schools]. Hirska shkola ukrainskykh Karpat. № 16. S. 24-33. URL: https://core.ac.uk/download/ pdf/154283942.pdf (data zvernennia: 07.02.2021). [in Ukrainian].
Erikson, E. (1996). Detstvo i obshchestvo [Childhood and society]; per. s angl. Sankt-Peterburg: Lenato, AST, Fond «Universitetskaya kniga». 592 s. [in Russian].

Kushnir, R. (2015). Treti 100000 krokiv do uspikhu [The third 100,000 steps to success]. Drohobych: Kolo. 152 s. [in Ukrainian].

Velykyi tlumachnyi slovnyk suchasnoi ukrainskoi movy [Great explanatory dictionary of modern Ukrainian language] (2005) / ukl. i hol. red. V. T. Busel. Kyiv; Irpin: Perun. 1728 s. URL: http://irbis-nbuv.gov.ua/ulib/ item/UKR0000989 (data zvernennia: 30.04.2021). [in Ukrainian].

Дата надходження до редакиї: 21.05.2021 p.
УДК 37.018.32:316.362

DOI: $10.37026 / 2520-6427-2021-106-2-88-93$
Катерина КОВАЛЬ,

здобувачка $\mathrm{PhD}$

Рівненського державного

гуманітарного університету,

м. Рівне, Украӥна

ORCID: 0000-0002-8139-1941

e-mail: Kateryna.koval@rshu.edu.ua

\section{СТАНОВЛЕННЯ ДИТЯЧОГО БУДИНКУ СІМЕЙНОГО ТИПУ ЯК ОСВІТНЬОГО ФЕНОМЕНУ}

Анотація. У статті схарактеризовано особливості становлення сочіального інституту виховання дітей-сиріт та дітей, позбавлених батьківського піклування, - дитячого будинку сімейного типу. Досліджено історичні передумови сімейного виховання дітей без батьківської опіки. Проаналізовано нормативно-правову базу організаиії дитячого будинку сімейного типу. Окреслено специфіку освітньо-виховної та сочіалізуючої діяльності дитячого будинку сімейного типу, де поєднуються родинне оточення та педагогічні методи соиіалізації.

Висвітлено поетапність діяльності дитячого будинку сімейного типу: підготовчий проиес батьків-вихователів, прийом дітей, період адаптаиії та взаємодії всіх членів родини. Підкреслено, щзо для коригування поведінки важливим є розуміння психологічного розвитку вихованців. Розкрито механізми педагогічного впливу та умови становлення особистості вихованців на прикладі батьків-вихователів за умови налагодження комунікаиії та емоційного контакту між дітьми та батьками, залучення всіх до прийняття рішень та створення позитивного освітньо-виховного й соціалізуючого середовищза.

Ключові слова: дитячий будинок сімейного типу, діти-сироти, діти, позбавлені батьківського піклування, батьки-вихователі, сімейна форма виховання, адаптація, соціалізація.

\author{
Kateryna KOVAL, \\ PhD graduate student \\ Rivne State University for the Humanities, \\ Rivne, Ukraine \\ ORCID: 0000-0002-8139-1941 \\ e-mail: Kateryna.koval@rshu.edu.ua
}

\section{ESTABLISHMENT OF A FAMILY TYPE ORPHANAGE AS AN EDUCATIONAL PHENOMENON}

\author{
Abstract. The article has characterized the \\ peculiarities of the establishment of a family type orphanage \\ as a social institution for upbringing orphans and children
}

whose parents were deprived of parental rights. The article has examined historical preconditions of the priority of family upbringing of children without parental care. 